\title{
Research of Marine Ferry Systems Based on Discretization pf Processes and Simulation Ferry Market Based on CIRCOS Intensity Graph
}

\section{Istraživanje sustavầ morskih trajekata temeljem procesa diskretizacije i simulacije tržišta trajekata na osnovi CIRCOS grafa intenziteta}

\author{
Srećko Krile \\ University of Dubrovnik \\ Electrical Engineering and \\ Computing Department \\ e-mail: srecko.krile@unidu.hr \\ Nikolai Maiorov \\ Saint-Petersburg State University of \\ Aerospace Instrumentation \\ Department of system analysis and logistics \\ Saint-Petersburg, Russia \\ e-mail: nmsoft@yandex.ru \\ Vladimir Fetisov \\ Saint-Petersburg State University of \\ Aerospace Instrumentation \\ Saint-Petersburg, Russia \\ e-mail: fet1@aanet.ru
}

DOI 10.17818/NM/2020/1.7

UDK 629.541.2:656.66

Preliminary communication / Prethodno priopćenje Paper accepted / Rukopis primljen: 7. 1. 2020.

\section{KEY WORDS}

mathematical model

simulation

ferry network

cruise network

transport hub

marine passenger port

passenger intensity

ferry line

planning

forecast

interpolation data on the Baltic and Adriatic seas. Based on the simulation results, a new system of corrective actions is proposed to improve the management of marine terminals. It presents new results which can increase the accuracy of the planning and decision-making process in predicting and planning the route network based on the research of passenger traffic between the «sea terminal - cruise line or ferry line» systems.

\section{Sažetak}

Danas postoji značajan porast uloge pomorskih trajektnih usluga, a jednako tako i porast broja trajekata i putničkoga prometa, koji zahtijeva razvoj novih praktičnih metoda predviđanja. Ovaj članak predlaže novi pristup predviđanjima, koji se temelji na integriranoj interakciji sustava putničke pomorske luke - broda za kružno putovanje ili trajekta. Ovo istraživanje usredotočilo se na područja Jadranskoga i Baltičkoga mora i postojeću mrežu ruta brodova za kružna putovanja i trajekata. Kada se proučava ovaj sustav, pokazalo se opravdanim koristiti novi matematički model temeljen na praktičnoj simulaciji i modelima teorije diskretnih procesa i sustava. Predloženi model nadopunjen je studijom koja se temelji na diskretnim procesima i sustavima na osnovi Kotelnikova teorema. Da bi se raspoznala dinamika promjena u takvome sustavu, predloženo je koristitinove dijagrame intenziteta, koji su predstavljeni CIRCOS grafovima (dijagramamima). Članak se bavi praktičnom važnosti korištenja novih CIRCOS grafova intenziteta odjeljaka da bi se proučilo djelovanje „pomorskoga terminala - brodova za kružna putovanja ili trajekata" sustava temeljenih na stvarnim podatcima o Baltičkome i Jadranskome moru. Na temelju simuliranih rezultata predlaže se novi sustav korektivnih djelovanja kako bi se poboljšalo upravljanje pomorskima terminalima. Predstavljaju se novi rezultati koji mogu povećati preciznost planiranja i proces odlučivanja u predviđanju i planiranju mreže ruta, temeljene na istraživanju sustava putničkoga prijevoza među „brodovima za kružna putovanja ili trajektnim linijama" (pomorski terminali).

\section{INTRODUCTION / Uvod}

Marine passenger ports and terminals are integral part of the transport complex of any region. They play a significant role in the processes of passenger service and transportation and are a link in the system as «ferry company - terminal - city system». These processes of formation have strong influence on historically established terminals near the historical centers of famous cities themselves. But today the segment of passenger shipping has increased significantly. Under the influence of the external environment, two trends emerged in the development of sea passenger terminals: 


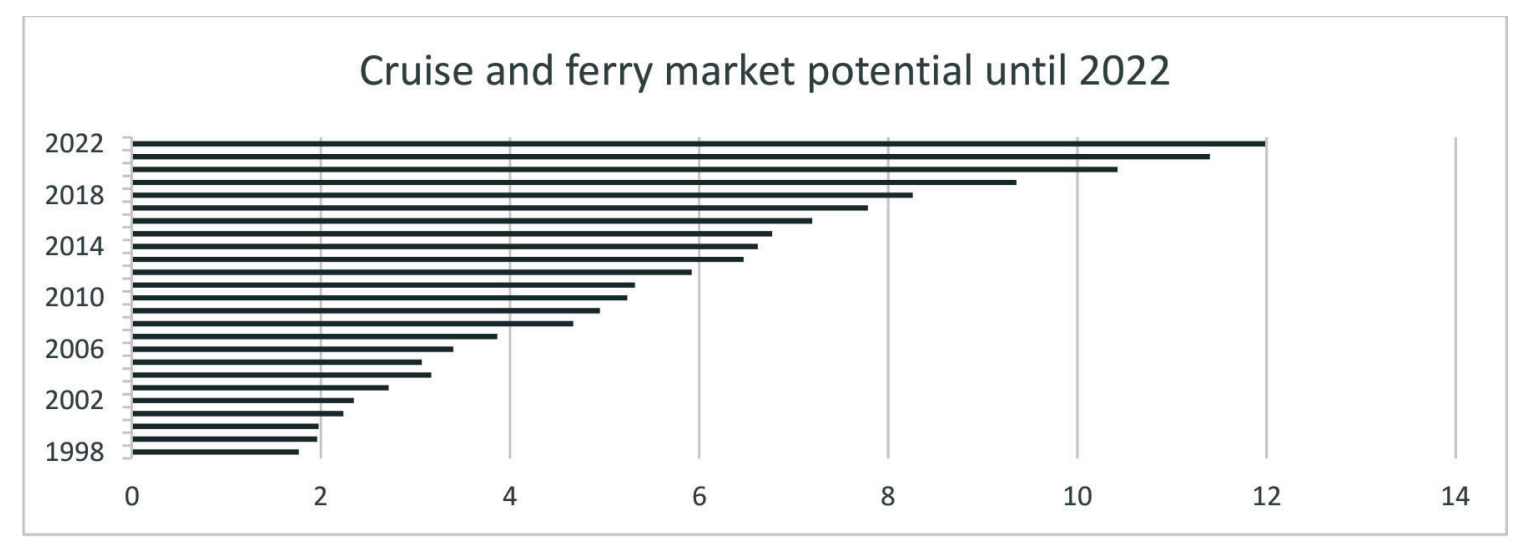

Figure1 Cruise market potential, mln. people (according to CINN 2018 EUROPE. European Cruise Lines) Slika 1. Tržište brodova za kružna putovanja u milijunima putnika (prema CINN 2018 EUROPE. European Cruise Lines)

1. trend of building large cruise liners;

2. construction of new separate terminals and expansion of ports to attract new passenger traffic;

3. changes in the route networks of ferry carrier companies, entering new markets, including new ports and terminals located in the northern seas on a cruise.

So, this transport marine industry is in the process of renovation, the construction of new marine terminals and the modernization of existing terminals. To confirm these trends we can look at the forecast data on fig. 1 shows (presents) the potential of the ferry and cruise transportation market until 2022 year [1,2]. Innovation refers to the construction of new terminals and changes in route networks.

Today, the main objects of research can be:

1. technological and organizational processes of a separate sea passenger terminal;

2. technological and organizational processes of a cruise or ferry company;

3. systems interaction of systems " marine ferry company passenger port - city megalopolis».

If the research of terminal processes leads to the solution of some problem of effective planning and organization, then the research of the interaction of systems requires the development of new dynamic models and methods. Especially such task is actual in forecasting of the development of the seaport/ terminal to preserve and increase passenger traffic and the intensity of cruise and ferry ships [3,4].

The development of the various components of the marine passenger port system firmly depends on significant increas of all activities and their quality level which shuold be forecast in the future periods. The main goal of any marine passenger port is to be effective and to ensure safety process of passenger transport by ferry or cruise ship.

Passenger port performance is evaluated on the basis of how well the traffic demands could be satisfied upon the facilities the system is handled with.

Over the years, certain techniques have evolved that enable passenger port planners and designers to forecast future demands and better planning of capacities. The principal items for that include the following:

operating characteristics of passenger port access systems; the volume, intensity and peaking characteristics of passengers, vessels and cargo;

the number and types of vessels and other resources needed to serve the above traffic.

In view of the fact that it is very difficult to predict the influence of the external environment on long-term traffic prediction of passenger terminals and the global market, it is proposed to use simulation modeling in the form of information transport models $[5,6]$. These technologies must solve various forecasting problems based on real data and tasks of operational processes $[7,8]$. Using simulation techniques, based on the estimation of these parameters and a determination of the peak period for volumes of passengers can be made [8, p. 28]. From these estimates, the concepts for the layout and sizing of sea terminal buildings, types of cruise and ferry ships, ships and ground access facilities may be examined. There are different approaches to simulation methods in transport logistics. The most suitable program on the market for creating transport models is Anylogic. This article provides an intelligent method based on discretization process and CIRCOS intensity graph .

\section{MODELS AND METHODS FOR SIMULATION SYSTEM «MARINE PASSENGER TERMINAL- FERRY LINE» BASED ON DISCRETIZATION / Modeli i metode za simulacijski sustav „Pomorski putnički terminal - trajektna linija" temeljen na diskretizaciji}

Simulation modelling is very suitable tool for analyzing and optimizing dynamic processes as we have in traffic forecasting. Specially it starts to be powerful tool when mathematical optimization of very complex systems becomes infeasible, and when our task is based on experiments in real systems that is too expensive, time consuming, or dangerous. The aim of simulation is to facilitate the objective decision making by means of dynamic analysis and to enable safely plan operations to managers. For scientific research of marine passenger processes in transport we mostly use such tools as follows: Linear programming; Network Optimization; Game Theory; Dynamic Petri networks; Decision Analysis; Markov Chains; Queuing Theory; Queuing system [6]. In the overview of the use of a large number of terminal schedules, it is necessary to use modeling based on the theory of discrete processes and systems. With this approach, it is necessary to introduce a new term for the state of the marine system. The state of the system is defined by some characteristics as the number of routes of ferry lines, the number of sea passenger terminals, the amount of passenger traffic and the traffic intensity of ferry ships. Based on the state of the marine system, we have to solve both: operational tasks 
and to evaluate forecasts in the development of the system and simulation. For detail, each state is characterized by a different capacity of the terminal, different passenger traffic and different workload of sea berths and services. A general view of the interaction of terminals is presented in fig. 2 .

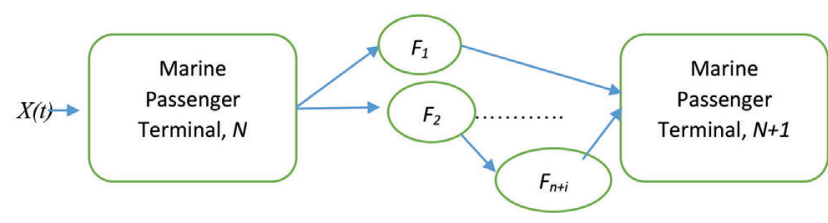

Figure 2 General scheme of interaction «marine passenger terminal- ferry line»

Slika 2. Opća shema interakcije „pomorskoga putničkoga terminala - trajektne linije"

In fig. $2 X(t)$ - Input intensity of cruise and ferry ships; $F_{1}, \ldots, F_{n+1}$ - various routes between terminals; $N, N+1$ - marine passenger terminal.

In the papers of some authors [8,9], to calculate the states of a system, it is necessary to determine possible state transitions. Since each state is characterized by a certain set of infrastructure variables, for their transitions it is necessary to calculate their probabilities. Let to ensure the smooth operation of the terminal involved no more than $n$ berths. At the entrance of the system comes the schedule of ship calls. Transitions of the system are represented in the form of a directed graph [10, p.189] and then the system is described by the Kolmogorov equations in the following form

$d p_{0}(t) / d t=\mu p_{1}(t)-\lambda(t) p_{0}(t)$,

$\ldots$

$\mathrm{dp}_{i}(t) / d t=\lambda(t) p_{i-1}(t)+(i+1) \mu p_{i+1}(t)-(\lambda(t)+i \mu) p_{i}(t) \quad(i=1,2, \ldots, \mathrm{n}-1)$

$\ldots$

$\mathrm{dp}_{n}(t) / d t=\lambda(t) p_{n-1}(t)-n \mu p_{n}(t)$

and boundary condition $\sum_{i=1}^{n} p_{i}(0)=1$,

where $\lambda(t), \mu(t)$ is a function of the intensity of transitions from one state to another; $i$ - the index corresponding to a particular state; $p_{i}(t)$ is the state probability function.

This set of equations accurately describes the transitions between different states for sea passenger terminals. Finding a solution to system (1) in general and for an arbitrary function presents considerable difficulties. The use of the Kotelnikov's theorem is proposed. This theorem allows finding the necessary system states. Any graph can be represented by a set of its discrete values. In our case the function of the marine system
$F(t)$, that is consisted of a certain discrete set of states, can be continuously determined with any accuracy using the values of the states following each other through $\Delta t=\frac{1}{F_{n}}$. The time moments of the system states are defined as $t_{k}=k \Delta t$, subject to the distance from each other for a time interval $\Delta t=\frac{1}{2 f}$. Recovery of any state of the system is determined by the formula

$$
x(t)=\sum_{k=0}^{K} x_{k} \frac{\sin \omega_{\hat{a}}(t-k \Delta t)}{\omega_{\hat{a}}(t-k \Delta t)},
$$

where $\omega=2 \pi f$.

The process of accurately finding the state of the system, according to the available discrete values, is represented in the following form of fig. 3 .

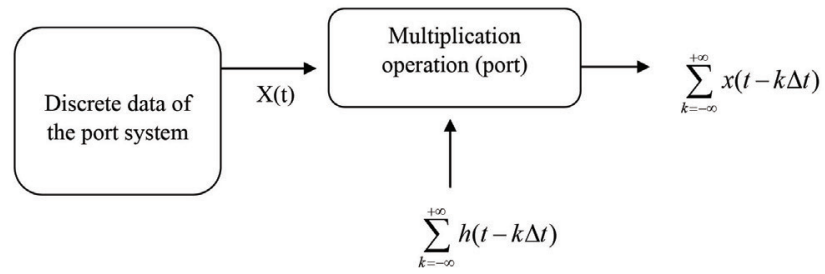

Figure 3 The process of discretization of system states Slika 3. Proces diskretizacije sistemskih stanja

In fig. 3 one input receives the initial continuous process $x(t)$ of the port system, the second input receives a system of single discrete values, following each other with a period. Then, after restoration of the state of the seaport system, the port manager should make corrective decisions to assess possible errors.

Consider restoring the state of the marine system based on the passenger port of Saint-Petersburg «Marine Façade» [16]. For the initial data, we take the total annual passenger traffic. So, we will take a discrete interval from 2014 to 2017 year and estimate the expected level of 2016. According to statistical information, passenger traffic amounted to 456495 passengers. In the general graph at this stage, there is a decrease compared with previous years. The equation for the calculation is as follows

$X_{2016}=F_{2014} \frac{\sin \left(\omega t_{2016}\right)}{\omega t_{2016}}+F_{2015} \frac{\sin \left(\omega t_{2016}-\pi\right)}{\omega t_{2016}-\pi}+F_{2017} \frac{\sin \left(\omega t_{2016}-2 \pi\right)}{\omega t_{2016}-2 \pi}$,

where $t_{2016}$ - discrete time for which we need to calculate the state of marine system; $F_{2014^{\prime}} F_{2015^{\prime}} F_{2017}$ values for passenger traffic.

Simulation based on the Kotelnikov theorem and recovery of system values by passenger traffic (fig. 4).

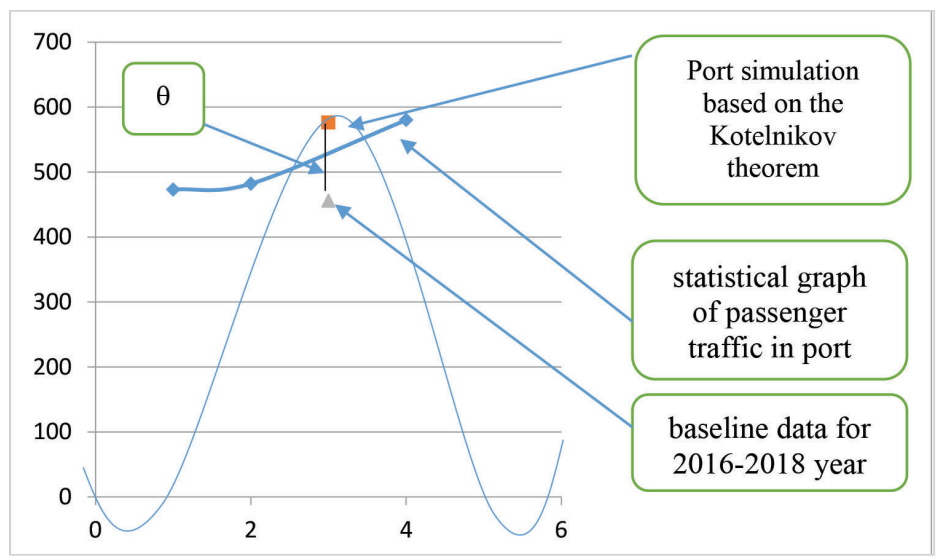

Figure 4 Realization of interpolation and modeling of system states using discrete values Slika 4. Realizacija interpolacije i modeliranja stanja sustava korištenjem diskretne vrijednosti 
Based on the result (fig.4), it turns out that, based on the available data, the passenger traffic for 2016 year should have been 561378 passengers. The discrepancy in the values is $\theta=104883$ passengers. This conclusion can be applied to any set of discrete states of the system and allows us to find any state. In this way, the mathematical models prove the discrete nature of the processes for passenger port and this model is correct. The real data for the model are passenger traffic and intensity of cruise ship and ferry ships. The obtained and reconstructed values must be used for modeling and subsequent decision-making. Based on this model, it is possible to evaluate the operation of the terminal and decide on the reasons for the failure to achieve the planned passenger traffic indicators.

\section{SIMULATION OF SYSTEM «MARINE PASSENGER TERMINAL- FERRY LINE» BASED ON CIRCOS DIAGRAM / Simulacija sustava „pomorski putnički terminal - trajektna linija" na osnovi CIRCOS dijagrama} In the passenger port sector, concerned with infrastructure development and the acquisition of handling equipment, forecasting is justified mainly by the potential traffic. Meeting of these demands is the purpose of any investment in a commercial port. Only in that way we can expect the development of any marine passenger port without first proving a minimum of traffic (passengers and cruise or ferry ships, their intensity and quality) to be handled. Thus, the quantification of potential traffic is the first step to introduce the decision making as a rational process. But, what way is much more actual now? At this moment, most effective way is the simulation methodology based on real dates and geo-information systems of passenger terminals. To simulate the workload of the sea passenger terminal, it is necessary to estimate the traffic intensity of cruise ships and ferry ships. Different capacity of passenger ships determines different load for the terminal. On the other hand, each terminal is interested in increasing the route network. Let's look on regions of the Adriatic and Baltic Seas.

The Croatian coast is connected with all inhabited islands by ferries. Also, the ferries connect Croatian ports with Italy and other nearest countries over the border line. The major Croatian passenger (cruise and ferry) ports are Split, Zadar, Rijeka, Šibenik and Dubrovnik. Dubrovnik, as one of the most popular destinations on the Adriatic Sea, and unique Europe's historically city, is the most prominent and popular vacation port for traveling by cruisers [12]. Ferries in the Baltic Sea, passenger shipping on the Baltic Sea serve as the backbone elements of the Baltic transnational macro-region [13, 14].

Table 1 presents data from open sources [12, 24, 25, 26, 27]. On the basis of the schedule of ship visits, it is possible to analyze the intensity of work for six months. According to the statistical data from EUROSTAT [15], given in table 2, there is a significant increase in passengers transported to/from main ports of Croatia in quarterly data. Cruise calls for port Dubrovnik behind six month 2019 presents on fig. 5 .

Table 1 Trends of traffic in some ports in Adriatic coast region

Tablica 1. Trendovi prometa u nekim lukama na obalnom području Jadrana

\begin{tabular}{|c|c|c|c|c|c|}
\hline & Parameters & Dubrovnik & Zadar & Split & Šibenik \\
\hline \multirow[t]{2}{*}{2014} & Cruise (pax) & 806412 & 53.791 & 184.062 & 12.693 \\
\hline & Cruise calls & 460 & 77 & 233 & 93 \\
\hline \multirow[b]{2}{*}{2015} & Domestic pax) & 452.904 & 2.156 .480 & & 259.106 \\
\hline & Cruise (pax) & 768.434 & 70.366 & 271.445 & 17.562 \\
\hline \multirow{3}{*}{2016} & Domestic (pax) & 479.634 & 2.238 .312 & & 276.234 \\
\hline & Cruise (pax) & 799.916 & 136.462 & 278.259 & 12.276 \\
\hline & Cruise calls & 529 & 114 & 286 & 105 \\
\hline 2017 & Domestic pax) & 594.609 & 2.348 .950 & & \\
\hline \multirow[t]{2}{*}{2018} & Cruise (pax) & 732.431 & 166,52 & & \\
\hline & Cruise calls & 414 & 120 & & \\
\hline
\end{tabular}

Sources: $[12,24,25,26,27]$

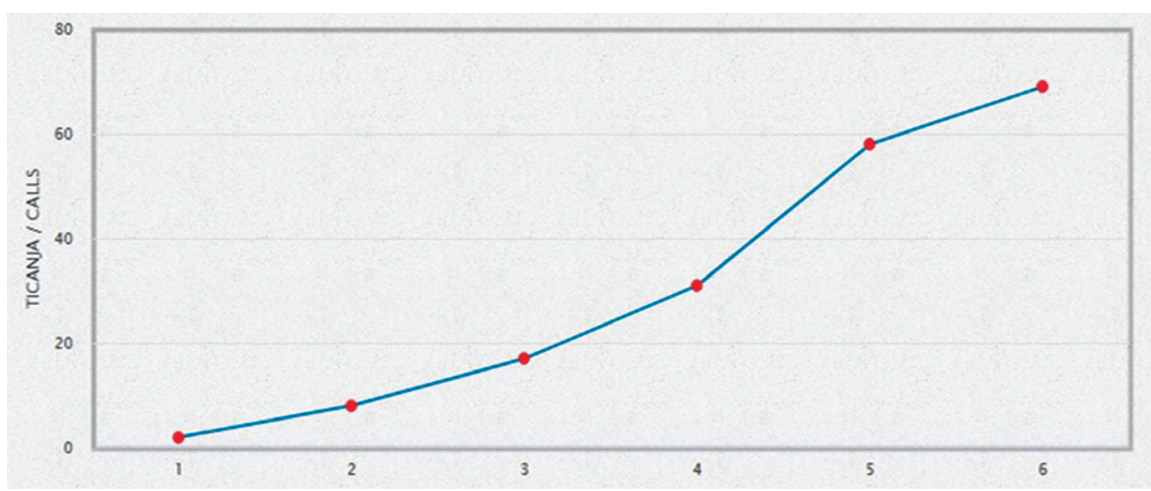

Figure 5 Cruise calls for port Dubrovnik last six months 2019

Slika 5. Ticanja brodova za kružna putovanja u zadnjih šest mjeseci 2019. god. 
Table 2 Passengers transported to/from main ports - Croatia - quarterly data (in thousand passengers)

Tablica 2. Putnici koji su se prevozili do glavnih luka i iz njih - Hrvatska - kvartalni podatci (u tisućama putnika)

\begin{tabular}{|l|r|r|r|r|r|r|r|r|r|r|r|r|}
\hline \multicolumn{1}{|c|}{ Ports } & $2016 /$ Q3 & $2016 / \mathrm{Q} 4$ & $2017 / \mathrm{Q} 1$ & $2017 / \mathrm{Q} 2$ & $2017 / \mathrm{Q}$ & $2017 / \mathrm{Q} 4$ & $2018 / \mathrm{Q} 1$ & $2018 / \mathrm{Q} 2$ & $2018 / \mathrm{Q} 3$ & $2018 / \mathrm{Q} 4$ \\
\hline Dubrovnik & 691 & 103 & 38 & 357 & 777 & 117 & 30 & 374 & 827 & 130 \\
\hline Poreč & 150 & 10 & 0 & 56 & 160 & 11 & 0 & 58 & 157 & 14 \\
\hline Preko & 706 & 328 & 294 & 451 & 724 & 324 & 283 & 451 & 737 & 323 \\
\hline Pula & 242 & 55 & 20 & 168 & 231 & 58 & 21 & 173 & 248 & 62 \\
\hline Rovinj & 29 & 3 & & 10 & 38 & 1 & & 17 & 59 & 4 \\
\hline Šibenik & 286 & 60 & 37 & 139 & 286 & 60 & 34 & 154 & 276 & 62 \\
\hline Split & 2170 & 594 & 441 & 1117 & 2190 & 591 & 445 & 1212 & 2369 & 625 \\
\hline Zadar & 918 & 378 & 333 & 542 & 960 & 372 & 322 & 551 & 980 & 375 \\
\hline
\end{tabular}

Sources: [15]

By the Baltic macro region, that means an integrated international region that includes the entire set of economic activities and represents a network model of cooperation with the presence of both horizontal and vertical links. With the efforts of 52 seaports out of 184, providing services for both cruise and ferry transportation of passengers [23, p.58]. The Baltic region is unique due to the proximity of various countries and the opportunity to get acquainted with a large cultural layer during one cruise. According to the source [15, 16, 17], only from 10 to 16 June 2019 , the passenger port was visited by nine cruise ships, on which 25660 passengers arrived. In total, the ships stayed at the port berths for 17 ship-days, the total number of passenger operations performed was 100,985. Additionally, it is necessary to note the fact that the number of days of maximum load of the passenger terminal significantly increases. When the terminal was at the same time from 5 to 7 ships, the number of loading days was 46 days, which is $31.4 \%$ more than last year's navigation. For example, on June 30, 2018, a new record for the number of passengers received per day was set in the passenger port of St. Petersburg. 18198 tourists descended from the six cruise ships to the coast. That is why, on the basis of a study of the carrying capacity of the passenger port, the possibility of more efficient scheduling of services and divisions opens up. Capacity means the maximum number of passengers and cruise ships that a passenger terminal can handle in accordance with its production capabilities for a certain period. The capacity of the passenger terminal as a whole depends on the capacity of its individual elements and services. When using simulation modeling of the terminal, it is possible to improve the quality of planning, since this is the way to confirm the correctness of organizational decisions. In [8], the developed tools are presented, which allow to plan terminal operation based on modeling in the AnyLogic environment.

Based on real data of passenger port St. Petersburg "Sea Facade", there is a significant increase in passenger traffic and the intensity of ferry or cruise ships, compared to 2016-2017. Of course, in addition to stimulating the attraction of foreign tourists arriving by cruise and ferry ships, there is a visa-free regime for 72 hours in Russia.

For the formation of conditions for effective planning of the work of the marine passenger terminal, we choose the intensity of cruise lines as a basis. Based on the analysis of ship call schedules for 2018, passenger capacity was determined and vessel call schedules were built (Fig. 6). Based on this analytics, we can explore the workload of the terminal. Thanks to the replay of ships for navigation in 2019, you can plan the operation of the terminal and, if possible, optimize it. Consider a fragment of the schedule of visits of cruise ships to the port (table 3).

Table 3 The some fragment of list of cruise ships calling at the port in navigation in 2018 in the Passenger Port of Saint-Petersburg "Marine Façade"

Tablica 3. Neki fragmenti liste brodova za kružna putovanja koji su u plovidbi tijekom godine 2018. ticali putničku luku Sankt Peterburga - "Marine Façade "

\begin{tabular}{|c|c|c|c|}
\hline Cruise ship & Berths in use at the port & Country & Passenger capacity \\
\hline Viking Sea & $1,2,3,4$ & Norway & 930 \\
\hline MSC Preziosa & $1,5,7$ & Panama & 4378 \\
\hline Regal Princess & $1,5,7$ & Bermuda & 4272 \\
\hline AIDAcara & $2,3,5,6$ & Italy & 1186 \\
\hline Rotterdam & 1,5 & Netherlands & 2220 \\
\hline Brilliance of the Seas & $1,5,7$ & Bahamas & 2500 \\
\hline AIDAmar & $1,3,5,6,7$ & Italy & 2500 \\
\hline Zenith & $1,3,5,6$ & Malta & 1442 \\
\hline AIDAdiva & $1,2,3,5,6,7$ & Italy & 2500 \\
\hline Zuiderdam & $5,6,7$ & Netherlands & 1916 \\
\hline Celebrity Silhouette & $1,5,7$ & Malta & 2850 \\
\hline MSC Orchestra & $1,6,7$ & Panama & 3060 \\
\hline Costa Magica & $1,5,6,7$ & Italy & 3470 \\
\hline Norwegian Breakaway & 1,7 & Bahamas & 3963 \\
\hline AIDAbella & $1,2,5,6,7$ & Italy & 2500 \\
\hline
\end{tabular}



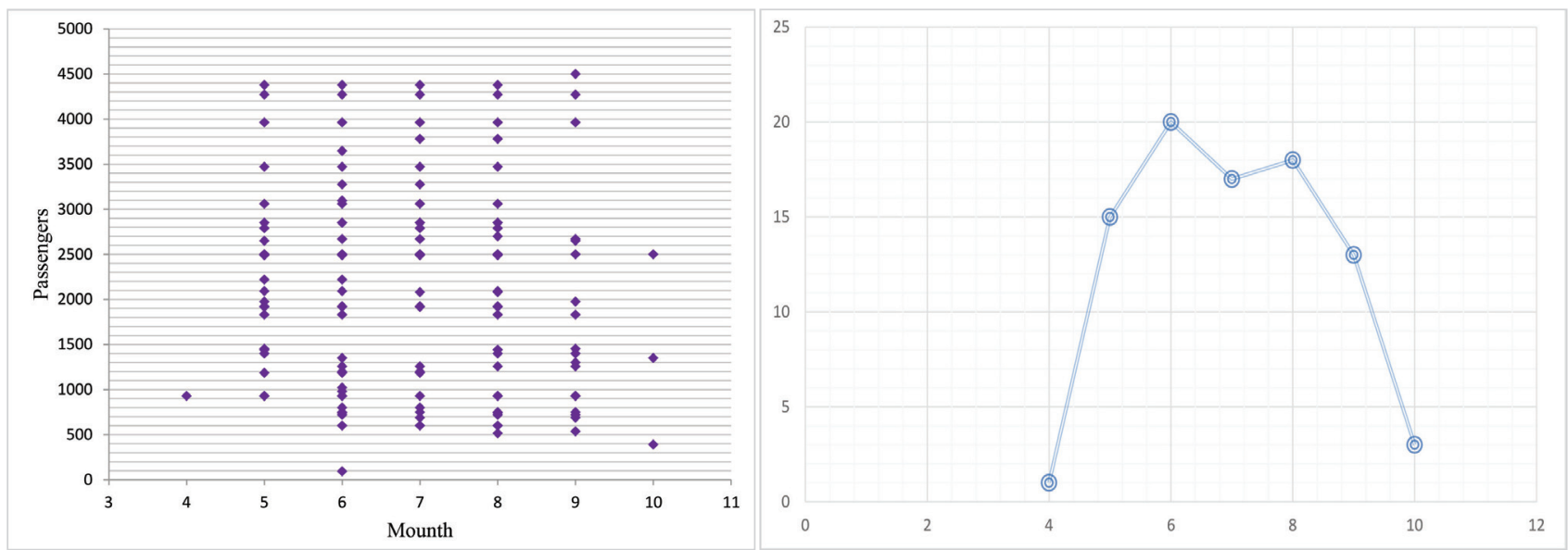

Figure 6 Ship call schedules for 2018 and passenger capacity in Passenger Port of Saint-Petersburg "Marine Façade" Slika 6. Raspored ticanja brodova za godinu 2018. i putnički kapacitet putničke luke Sankt Peterburg „Marine Façade”

To simulate the operation of the system «marine passenger terminal- ferry line», the article $[18,19,20,21]$ suggests using CIRCOS diagram. With this approach, the communication diagram provides a structured overview to the analysis of complex interactions between passenger terminals, which is its strength. Also, the diagram on its elements allows interaction with additional analytical information, such as work intensity, workload and others. Ferry traffic intensities and simulation results based on the Circos plot diagram are presented in Fig. 7.
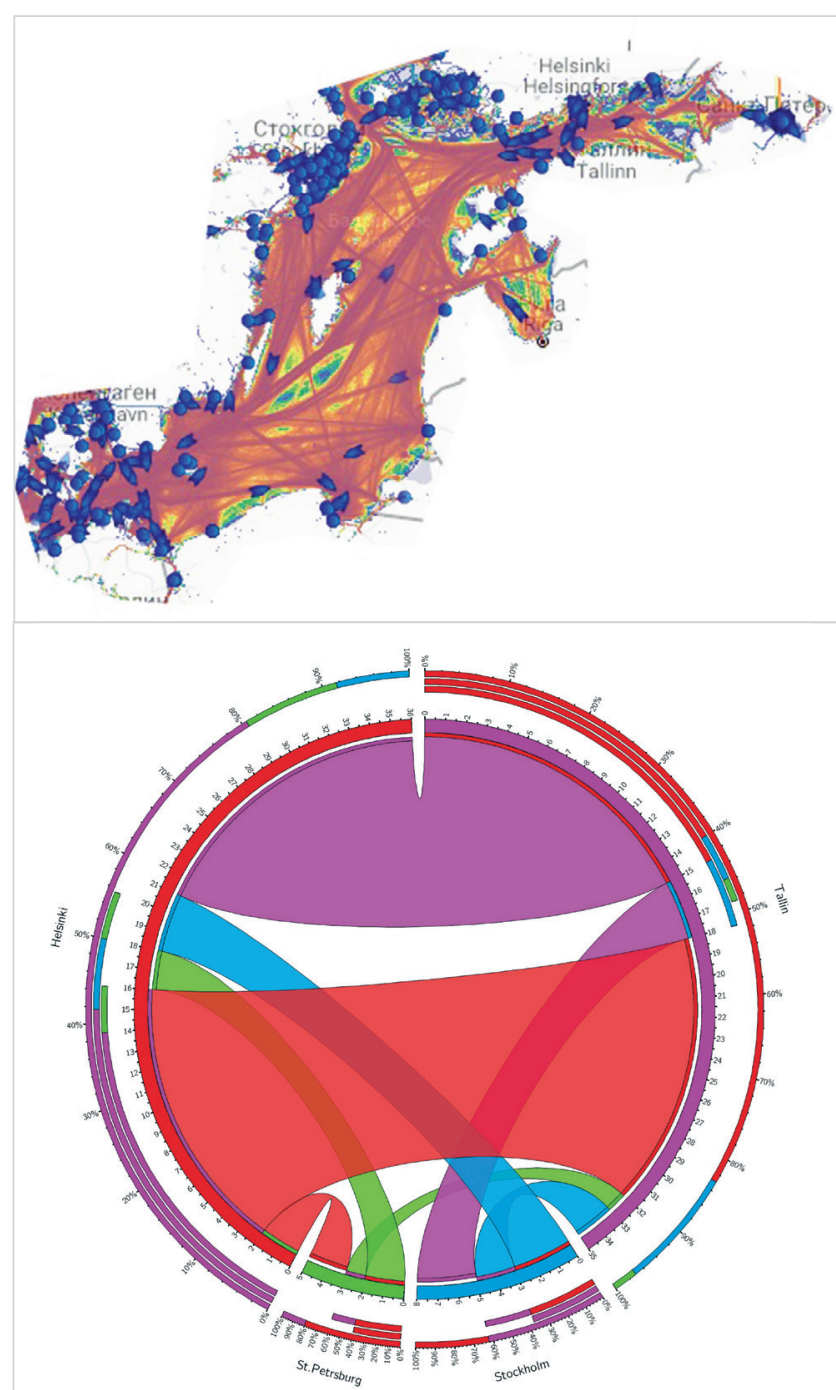

a)
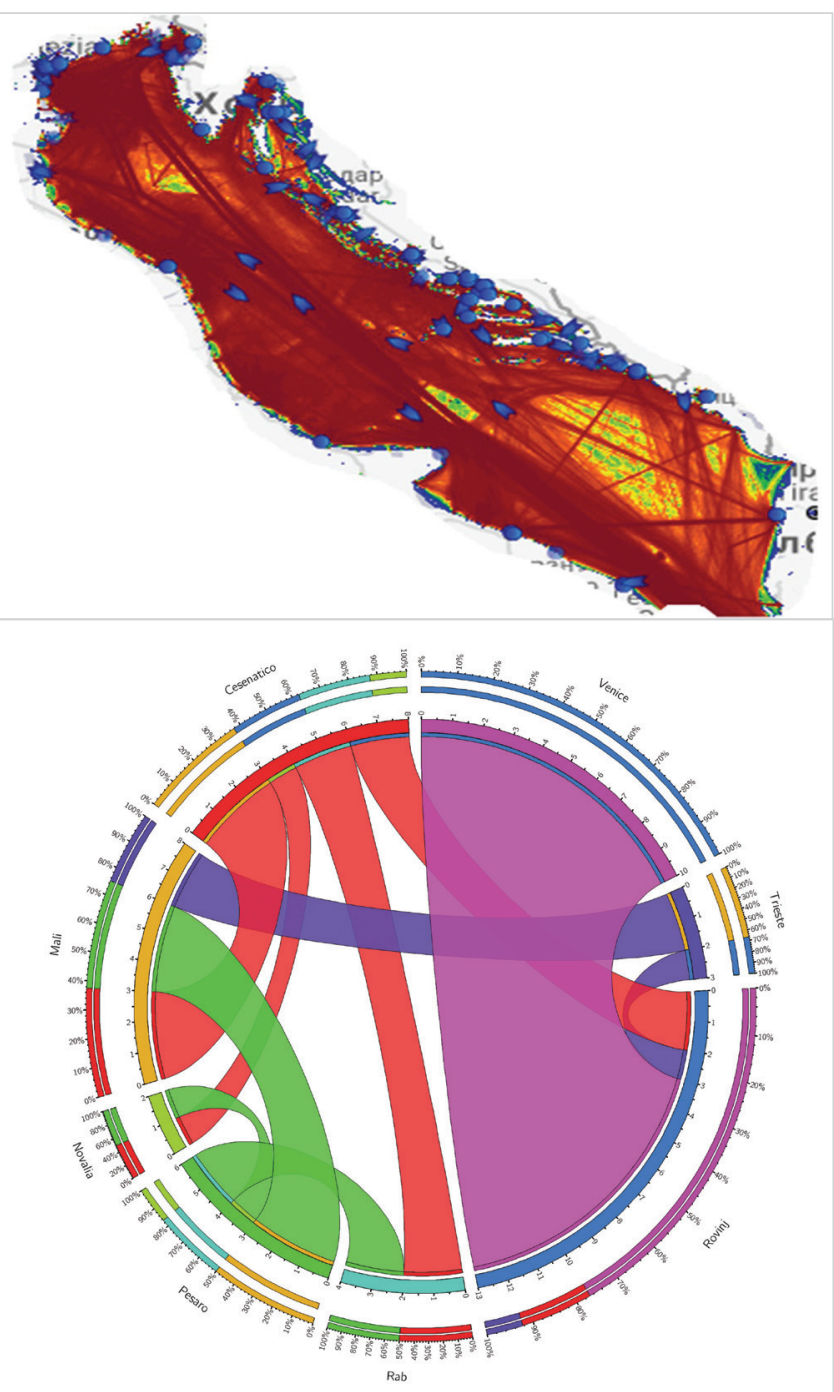

b)

Figure 7 The results of the simulation system «marine passenger terminal- ferry line» work for the terminals of the Baltic (a) and Adriatic (b) seas

Slika 7. Rezultati sustava simulacije „pomorskoga putničkoga terminala - trajektne linije“ za terminale: a) Baltičkoga i b) Jadranskoga mora 


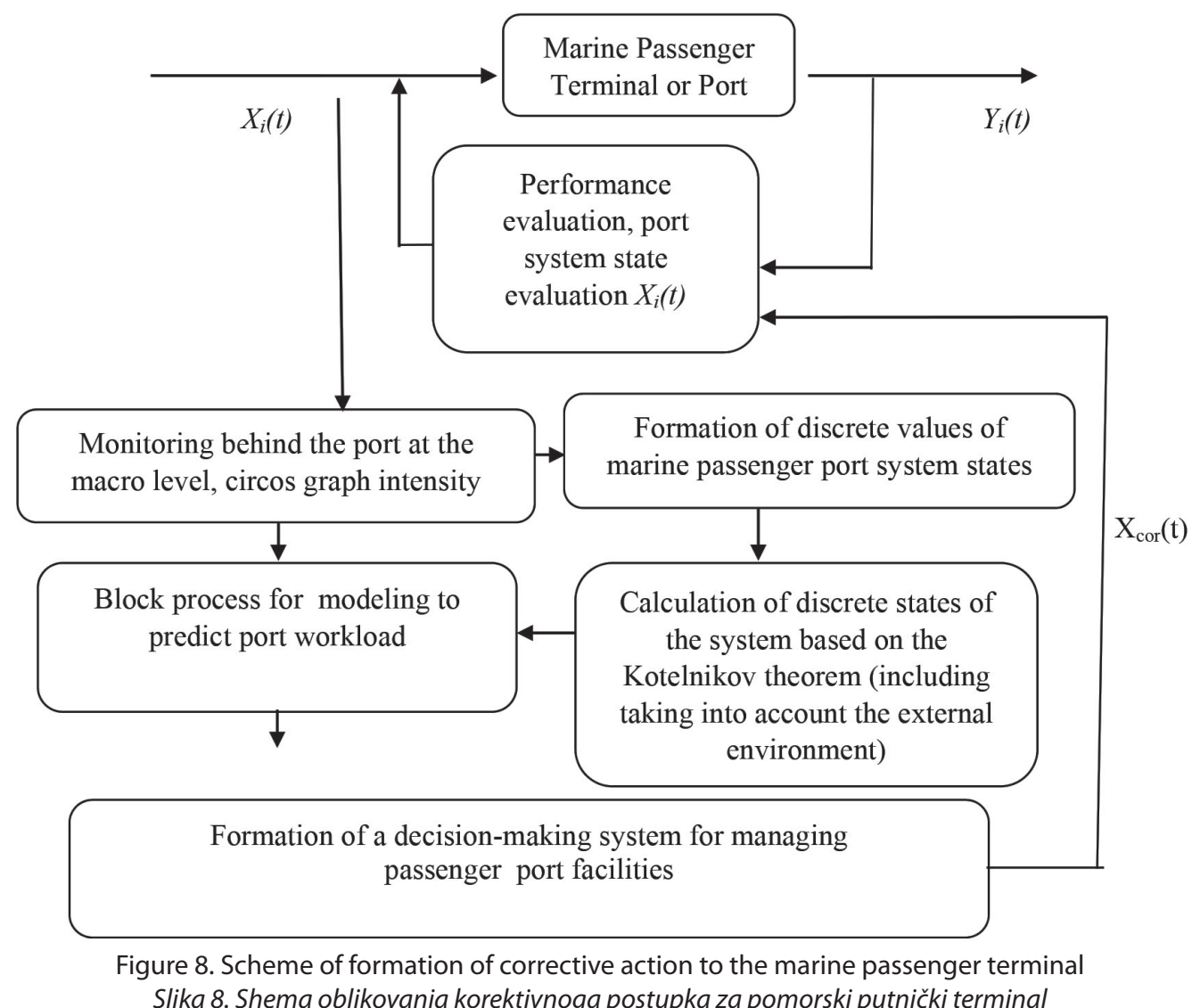

The information graphs (fig.7) also contains analytical information on the mutual influence of passenger ports [22], presented in the form of circular graph (circos diagram ). This analytical data allows us to introduce the decision making process, with traffic prediction already at the macro level of terminal planning. It also provides very important information on the mutual influence of terminals in the regions of seas. As a result, the use of this circos diagram (graph) with the presentation of traffic intensity makes it possible (at the macro level) to investigate the operation of the «maritime passenger terminal - ferry line» system.

\section{DECISION MAKING PLAN FOR CORRECTIVE ACTION TO THE MARINE PASSENGER TERMINAL / Plan odlučivanja za ispravni postupak kod pomorskoga putničkoga terminala}

Based on the simulation results, the decision maker should form a system of making corrective decisions to minimize errors in the operation of the seaport. The general scheme of the formation of corrective actions (Fig. 8).

In Figure $8, X(t)$ is the input intensity of cruise and ferry ships, $Y(t)$ is the number of ferry and cruise ships processed by the system. To form a corrective action, monitoring of the state of the passenger marine port, ferry's route networks in region is simultaneously used, as well as the recalculation of port system states based on a set of discrete states based on the original schedule data. The received planned data will be sent to the decision-making system for determining the port load and schedule adjustment scheduling and work. When performing the corrections (feedback structure), inconsistencies in the planned indicators will be found and the task of work planning will be made.

Based on fig. 8 and the proposed methodology for simulation

of the operation of the system, taking into account the corrective action $X$ cor ( $t$ ) of the system states is added to the control decision loop. The calculations are based on simulation, the use of a circos graph, the interpolation of system states on the basis of the Kotelnikov theorem. At the same time, this technique should be used in parallel with the unit for simulation operational activities. Based on the simulation, the predicted load of the infrastructure elements is determined and then the states are calculated, while using the proposed technique it is possible to directly calculate the required state of the port system.

Implementation of this decision-making system requires organizational changes. So, it is necessary to create a separate analytical department that will collect data from all processes of the marine passenger terminal. The implementation requires the creation of a specialized information transport model, for example in the AnyLogic environment, connected to the real information systems of individual terminal processes. This model will allow the research of the processes of the sea terminal at all the levels of management. From the research of one process, for example, inspection or check-in of passengers, to research of the work of the whole system. This approach will allow to collect the data and improve the quality of forecasting the development of the marine passenger terminal.

\section{CONCLUSION / Zaključak}

When studying the development tasks of marine passenger terminals, it is necessary to use flexible tools and techniques. As it is well known, under the influence of the external environment, constant changes occur both in the route ferry networks and cruise lines, and in the organizational processes of each passenger marine terminals. The main information tool 
for making decisions on planning, optimization, forecasting is simulation modeling. However, effective using apparatus of simulation should be based on mathematical models and methods that accurately describe the real processes. The object of the study was selected regions of the Baltic and Adriatic seas and existing route networks of ferry lines and existing system of marine passenger ports and terminals.

The article proposes to use the new process discretization based on Kotelnikov's theorem to research the systems «marine passenger terminal - ferry or cruise line» system to determine the terminal capacity values and evaluate the operation processes of the terminal itself. The model can be used for any time interval of research. To confirm the correctness was used statistics information of passenger port of Saint Petersburg «Marine Façade». It is proposed to take into account the impact of the environment through a probabilistic function and take into account both positive and negative effects of the external environment. This approach can be used both in parallel with the operational modeling of the port system, and separately, for given discrete values. It can be used both at the macro level of the system and used to analyze individual nodes at the micro level. The proposed methodology is expected to be useful at the stage of operational management of the terminal and the feasibility study.

Then, it is proposed to use new circos plot diagrams to assess the impact of the terminal system of each other and research changes in the ferry transport market. This model can be scaled on any number of marine passengers terminals in region. When a system is formed from data diagrams built over a selected time interval, it is possible to justify system changes, which cannot be determined by working with separate tables and well known analytics models.

On the basis of a Kotelnikov's theorem and simulation market with circos intensity graph new scheme of corrective action for the marine passenger terminal is proposed. This way allows for a qualitatively new level to investigate the system «marine passenger terminal- ferry line» and significantly improves the accuracy of forecasting and planning tasks.

\section{REFERENCES / Literatura}

1. CINN 2018 EUROPE. European Cruise Lines Available at: https://www. cruiseindustrynews.com/pdf

2. Economic Impact of Cruise Activity: The Port of Barcelona. - IREA: 2016 - 30 p.

3. Unctad monographs on port management. The economic impact of cruise ports: The case of Miami. - New York and Geneva, 2001. - 33 p.

4. Handbook of Terminal Planning / edited by J. W. Böse. - Springer Science+Business Media, LLC, 2011. — 456 p. DOI: 10.1007/978-1-4419-8408-1.
5. AnyLogic. Available at: https://anylogic.com (accessed 01. 07. 2019).

6. Maiorov, N.; Fetisov, V. (2012). Prakticheskie zadachi modelirovaniia transportnykh sistem [Practical Problems of Modeling of Transport Systems] Saint Petersburg: SUAI Publ., 185 pp. (In Russian)

7. Maiorov, N. N.; Fetisov, V. A.: Improvement of the quality of the sea passenger terminal based on methods of forecasting. Naše more (Our Sea). 2018. Vol 65. No. 3. pp. 135-140 https://doi.org/10.17818/nm/2018/3.1

8. Krile, S.; Maiorov, N.; Fetisov, V.: Forecasting the operational activities of the sea passenger terminal using intelligent technologies, Transport Problems, 2018 Vol.13 (Issue 1), pp. 27-36. https://doi.org/10.21307/tp.2018.13.1.3

9. Ivanov, B. A.; Nedviga, A. V. (2007). Elementy teorii diskretnykh sistem avtomaticheskogo upravleniya. Ukhta: UGTU, 112 p. (In Russian)

10. Vencel', E. S. Teoriya sluchajnyh processov ee inzhenernye prilozheniya. M.: Nauka, 1991.

11. Naumova, N.; Danovich, L. A.: Model of flows distribution in the network. Life Science Journal. 2014. No. 11(6). P. 591-597.

12. Passengers transported to/from main ports - Croatia - quarterly data. Available at: http://appsso.eurostat.ec.europa.eu/nui/show.do?dataset=mar_pa_qm_ hr\&lang=en (accessed 1 July 2019)

13. Cruise Europe. Port Handbook (2018). http://www.cruiseeurope.com/ (accessed: 15. 4. 2018)

14. Baltic Port list 2006. Annual cargo statistic of ports in the Baltic Sea region / A publication from the center for maritime studies university of Turku: - Turku, 2012. $120 \mathrm{p}$.

15. Passengers transported to/from main ports - Croatia - quarterly data. Available at: http://appsso.eurostat.ec.europa.eu/nui/show.do?dataset=mar pa_qm_hr\&lang=en (accessed 11 February 2019)

16. HELCOM.fi. Available at: http://maps.helcom.fi/website/AlSexplorer/ (accessed 01. 07. 2019).

17. Passenger Port of Saint-Petersburg „Marine Façade". Available at: https://www. portspb.ru/

18. Circos. Available at: https://sourceforge.net/projects/jcircos/ (accessed 11. 10 2019).

19. Judith Mulder; Rommert Dekker: Methods for strategic liner shipping network design. European Journal of Operational Research .2014.Vol. 235 ( Issue 2), P. 367-377. https://doi.org/10.1016/j.ejor.2013.09.041

20. Fagerholt, K.: Fleet deployment in liner shipping: a case study / K.Fagerholt, T. A. V. Johnsen, H. Lindstad// Maritime Policy \& Management.2009. vol. 36. no. 5. P. 397-4096.https://doi.org/10.1080/03088830903187143

21. Agarwal, R.: Ship Scheduling and Network Design for Cargo Routing in Liner Shipping / R. Agarwal, O. Ergun // Transportation Science. 2008. vol. 42. no. 2. P. 175-19. https://doi.org/10.1287/trsc.1070.0205

22. Barron, P.; Greenwood, A. B.: Issues determining the development of cruise itineraries: a focus on the luxury market. Tourism in Marine Environments. 2006. 3(2). P. 89-100. https://doi.org/10.3727/154427306779435238

23. Krile, S.; Maiorov, N. N.: Work Analysis of Maritime Passenger Terminals for Particular Region Based on Circos Plot. Naše more (Our Sea). 2019. Vol 66. No. 2. pp. 57-61. https://doi.org/10.17818/nm/2019/2.2

24. Port Dubrovnik. Available at: https://www.portdubrovnik.hr (accessed 11. 10. 2019).

25. Port Split. Available at: https://portsplit.hr (accessed 11. 10. 2019).

26. Port Sibenik. Available at: http://www.portauthority-sibenik.hr (accessed 11. 10. 2019).

27. Port Zadar. Available at: http://www.port-authority-zadar.hr (accessed 11. 10. 2019).

Note: Some of the research results were presented at the Naše more 2019 conference. 